\title{
ДОЦІЛЬНІСТЬ ВИКОРИСТАННЯ ПРЕПАРАТУ L-БЕТАРГІН У ХВОРИХ НА ЦУКРОВИЙ ДІАБЕТ 2 ТИПУ ТА ХРОНІЧНИЙ ПАНКРЕАТИТ
}

\author{
๑€. С. Сірчак, В. Є. Барані, С. С. Сірчак, О. Ю. Рего \\ ДВНЗ «Ужгородський національний університет»
}

РЕЗЮМЕ. На сьогодні цукровий діабет (ЦД), як і хронічний панкреатит (ХП), є серйозною медико-соціальною проблемою в зв' язку зі збільшенням поширеності і прогресуючою тенденцією до їх зростання.

Мета - вивчити клініко-лабораторну ефективність використання амінокислотного комплексу L-Бетаргін у хворих на ЦД 2-го типу та ХП.

Матеріал і методи. Обстежено 76 хворих на ЦД 2-го типу та ХП. Хворих, залежно від призначеного лікування, поділили на дві групи: I група ( $n=40)$ обстежених хворих отримувала лише базисне лікування (БЛ); II групі (n=36) обстежених пацієнтів додатково до БЛ призначали амінокислотний комплекс L-Бетаргін по 10 мл 3 рази на добу протягом 1 місяця. Усім обстеженим пацієнтам проводили загальноклінічні дослідження, а також визначення вітамінного забезпечення та рівня гомоцистеїну.

Результати. Проведена терапія виявилась ефективнішою за впливом на динаміку клінічних проявів у хворих II групи, які додатково отримували амінокислотний комплекC L-Бетаргін. При цьому диспептичні прояви зменшились у 4,7 раза, тоді як у хворих I групи - лише у 2,6 раза $(p<0,01)$. Додаткове призначення амінокислотного комплексу до БЛ у обстежених хворих сприяло більш вираженій позитивній динаміці показників вуглеводного обміну. Встановлено статистично достовірне зниження рівня НbA1с (до $(6,02 \pm 0,16) \%)$, інсуліну (до $(11,33 \pm 0,84)$ Од/л),

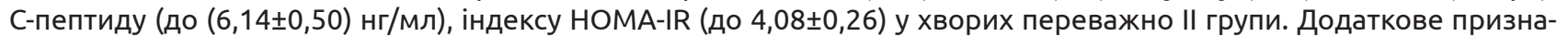
чення L-Бетаргіну також приводить до статистично достовірного зниження рівнів загального холестерину, тригліцеридів, ліпопротеїдів низької щільності $(p<0,05)$ та підвищення вітамінів групи $\mathrm{B}$, що супроводжується зниженням показника гомоцистеїну у хворих на ЦД 2-го типу та ХП.

Висновки. Комплексна терапія із використанням препарату L-Бетаргін $\epsilon$ ефективним методом для корекції клінічних та лабораторних порушень (показників ліпідного, вуглеводного обмінів, вітамінного забезпечення та рівня гомоцистеїну в сироватці крові) у хворих на ЦД 2-го типу та ХП.

КлючОВІ СЛОВА: цукровий діабет 2-го типу; хронічний панкреатит; лікування; L-Бетаргін.

Вступ. Цукровий діабет (ЦД) та хронічний панкреатит (ХП) становлять серйозну медико-соціальну проблему в зв'язку зі збільшенням поширеності та прогресуючою тенденцією до їх зростання [1]. Цукровий діабет - особливе захворювання, на фоні якого в останні роки відзначається зростання коморбідних патологій [2].

Хронічний панкреатит також належить до найскладніших поліетіологічних і поліморбідних захворювань [3]. Проведені дослідження ланок патогенезу ХП за умов різноманітної коморбідності доводять важливу роль системного запалення, дисбалансу про- та протизапальних цитокінів, чинників протеїназоінгібіторної системи зі зростанням негативного впливу системного протеолізу, порушення оксидантно-антиоксидантного гомеостазу з активацією оксидативного та нітрозитивного стресу на тлі дефіциту природних антиоксидантів $[4,5]$.

При ЦД порушуються всі види обміну речовин, у результаті чого в тому чи іншому ступені уражаються всі органи і системи організму, в тому числі й система органів травлення (шлунок, кишечник, печінка, підшлункова залоза). Це як власне гастроінтестинальні зміни (дисфункція стравоходу, гастропатія, сповільнення евакуаторної функції шлунка, діабетична діарея, запори, нетри- мання калу), в основі яких лежить діабетична нейропатія [6], так і стани, пов' язані з гормонально-метаболічними порушеннями, що $є$ наслідком порушеного тканинного метаболізму. Отже, у 75 \% випадків ЦД супроводжується ураженням системи органів травлення, що впливає на вибір тактики лікування [2].

Отже, пошук високоефективних засобів лікування коморбідної патології, що можуть впливати одночасно на декілька патогенетичних ланок формування ускладнень, як при ЦД 2-го типу, так і при $X П, \epsilon$ одним із важливих завдань сучасної клінічної медицини. Такими засобами можуть бути амінокислотні комплекси, які мають антиоксидантну, детоксикаційну, мембраностабілізувальну властивості, а також ефективно нормалізують метаболічні процеси, в тому числі й порушений ліпідний обмін в організмі.

Мета - вивчити клініко-лабораторну ефективність використання препарату L-Бетаргін у Хворих на ЦД 2-го типу та ХП.

Наукове дослідження $\epsilon$ фрагметном наукової теми кафедри пропедевтики внутрішніх хвороб «Поліморбідна патологія при захворюваннях органів травлення, особливості патогенезу, можливості корекції» (номер державної реєстрації 0118U004365). 
Огляди літератури, оригінальні дослідження, погляд на проблему, випадок з практики, короткі повідомлення

Матеріал і методи дослідження. Під нашим спостереженням перебували 76 хворих на ХП та ЦД 2-го типу. Серед обстежених було 40 (52,6 \%) чоловіків і 36 (47,4 \%) жінок. Середній вік становив $(48,7 \pm 5,9)$ років. Обстежені хворі перебували на стаціонарному лікуванні в ендокринологічному та гастроентерологічному відділеннях КНП «ЗОКЛ імені А. Новака» ЗОД, у хірургічному відділенні № 1 Мукачівської центральної районної лікарні імені Святого Мартина, а також знаходились на амбулаторно-диспансерному спостереженні у дільничного сімейного лікаря за місцем проживання.

У контрольну групу ввійшли 20 практично здорових осіб (11 чоловіків (55,0 \%), 9 жінок (45,0%). Середній вік складав $(45,2 \pm 5,1)$ років.

Усі дослідження виконувались за згодою пацієнтів, а методика їх проведення відповідала Гельсінській декларації прав людини 1975 р. та її перегляду 1983 р., Конвенції Ради Європи про права людини і біомедицину та законодавству України.

Усім обстеженим пацієнтам проведено загальноклінічні, антропометричні, інструментальні та лабораторні дослідження. Обстеженим хворим до та після комплексного лікування у сироватці крові проведено стандартні загальні та біохімічні дослідження з акцентом на показники вуглеводного (глюкози, глікозильованого гемоглобіну, інсуліну, С-пептиду, проінсуліну) та ліпідного (загальний холестерин (3X), тригліцериди (ТГ), ліпопротеїди низької щільності (ЛПНЩ), ліпопротеїди дуже низької щільності (ЛПДНЩ), ліпопротеїди високої щільності (ЛПНЩ), аполіпопротеїн А та В) обмінів. Усім обстеженим пацієнтам до та після лікування проведено визначення рівня гомоцистеїну в сироватці крові із використанням тест-системи Cobas 8000 (Roche Dianostics), а також вітамінів $\mathrm{B}_{1}$ (тіамін) та $\mathrm{B}_{6}$ (піридоксин) за допомогою високоефективної рідинної хроматографії із використанням тест систем (Recipe complet Kit, Німеччина); вітаміну $\mathrm{B}_{9}$ (фолієва кислота) - за допомогою імунохімічного методу 3 електрохемілюмінесцентною детекцією, використовуючи тест-системи Roche Diagnostics (Швейцарія) та вітаміну $\mathrm{B}_{12}$ (ціанокобаламін) - за допомогою імунохімічної хемілюмінесцентної детекції, використовуючи тест системи Abbot Diagnostics (США).

Надання медичної допомоги обстеженим хворим на ЦД 2-го типу та ХП проводили згідно з клінічними протоколами МОЗ України та локальними протоколами. Діагноз ЦД 2-го типу встановлювали згідно з рекомендаціями IDF (2005 р.), а також із урахуванням критеріїв уніфікованого клінічного протоколу (Наказ МОЗ України від 21.12.2012
№ 1118) $[7,8]$. Ступінь тяжкості ЦД 2-го типу оцінювали за рівнем НbА1с (норма - до 6,0 \%).

Діагноз ХП встановлювали відповідно до марсельсько-римських критеріїв (1989 р.) з доповненнями Я. С. Циммермана (1995 р.) та уточненнями MKX-10, а також відповідно до Наказу МОЗ України від 10.09.2014 р. № 638. Для вивчення зовнішньосекреторної функції (ЗСН) підшлункової залози (ПЗ) проводили копрологічне дослідження, визначали рівень амілази сироватки крові та фекальної

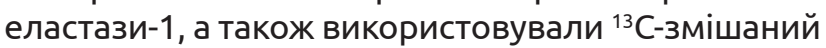
тригліцеридний та ${ }^{13} \mathrm{C}$-амілазний дихальні тести.

Хворим на ЦД 2-го типу та ХП на фоні модифікації способу життя та дієтичних рекомендацій призначено базисне лікування, що включало призначення пероральних цукрознижувальних препаратів (метформін та інгібітор дипептилпептидази-4 в індивідуальному дозуванні), а також індивідуально підібрану замісну ферментну терапію, спазмолітиків, прокінетиків. Хворих поділено на дві групи. I група (n=40) обстежених хворих на ЦД 2-го типу та ХП отримувала лише базисне лікування (БЛ); II групі (n=36) обстежених пацієнтів додатково до БЛ призначали амінокислотний комплекс L-Бетаргін (TOB «Ворфартс Фарма») по 10 мл 3 рази на добу протягом 1 місяця.

Аналіз і обробку результатів обстеження хворих здійснювали за допомогою комп' ютерної програми STATISTICA 10.0 (фірми StatSoft Inc, USA) 3 використанням параметричних та непараметричних методів оцінки отриманих результатів.

Результати й обговорення. У всіх пацієнтів, які перебували під нашим спостереженням, діагностовано ЦД 2-го типу середнього ступеня тяжкості, а також підтверджено діагноз ХП, що проявлялось порушенням ЗСН ПЗ за даними результатів клініко-лабораторних та інструментальних методів обстеження.

До лікування у хворих на ЦД 2-го типу та ХП ЗСН ПЗ проявлялась переважно диспептичними проявами, порушенням випорожнення (схильність до проносів) та больовим синдромом. Проведена терапія виявилась ефективнішою за впливом на динаміку клінічних проявів у хворих II групи, які додатково отримували амінокислотний комплекC L-Бетаргін. При цьому диспептичні прояви, що мали місце до лікування у 91,7 \% хворих II групи, зменшились у 4,7 раза, тоді як у хворих I групи - лише у 2,6 раза (р<0,01) (табл. 1).

Додаткове призначення амінокислотного комплексу до БЛ у обстежених хворих на ЦД 2-го типу та ХП сприяло більш вираженій позитивній динаміці показників вуглеводного обміну. Встановлено статистично достовірне зниження рівнів HbA1c, інсуліну, C-пептиду, індексу HOMA-IR у хворих переважно II групи (табл. 2). 
Огляди літератури, оригінальні дослідження, погляд на проблему, випадок з практики, короткі повідомлення

Таблиця 1. Динаміка клінічних проявів зовнішньосекреторної недостатності підшлункової залози у хворих на хронічний панкреатит та ЦД 2-го типу на фоні комплексної терапії

\begin{tabular}{|l|l|c|c|c|}
\hline \multirow{2}{*}{\multicolumn{2}{|c|}{\begin{tabular}{l} 
Обстежені \\
\cline { 2 - 4 } \multicolumn{2}{|c|}{}
\end{tabular}}} & \multicolumn{3}{|c|}{ Клінічні прояви } \\
\hline $\begin{array}{l}\text { I група } \\
\text { (n=40) }\end{array}$ & до лікування & 65,0 & $\begin{array}{c}\text { порушення } \\
\text { випорожнення, \% }\end{array}$ & диспептичні прояви, \% \\
\hline $\begin{array}{l}\text { II група } \\
\text { (n=36) }\end{array}$ & після лікування & $45,0^{*}$ & 75,0 & 90,0 \\
\cline { 2 - 5 } & до лікування & 63,9 & $45,0^{*}$ & $35,0^{* *}$ \\
\hline
\end{tabular}

Примітка. Показник у хворих до та після лікування по групах достовірний: * $-p<0,05 ;$ ** $-p<0,01$; різниця між показником у хворих I та II груп після лікування достовірна: +- p $<0,05$.

Таблиця 2. Динаміка показників вуглеводного обміну в обстежених хворих на ЦД 2-го типу та хронічний панкреатит на фоні проведеного лікування

\begin{tabular}{|c|c|c|c|c|c|}
\hline \multirow{3}{*}{ Показник } & \multirow{3}{*}{$\begin{array}{c}\text { Контрольна } \\
\text { група } \\
(n=20)\end{array}$} & \multicolumn{4}{|c|}{ Обстежені хворі } \\
\hline & & \multicolumn{2}{|c|}{ І група $(n=40)$} & \multicolumn{2}{|c|}{ II група $(n=36)$} \\
\hline & & до лікування & після лікування & до лікування & після лікування \\
\hline $\begin{array}{l}\text { Глюкоза в крові натще, } \\
\text { ммоль/л }\end{array}$ & $4,55 \pm 0,26$ & $9,46 \pm 0,19$ & $7,12 \pm 0,25 *$ & $9,51 \pm 0,28$ & $6,86 \pm 0,44^{*}$ \\
\hline HbA1c, \% & $4,20 \pm 0,29$ & $8,62 \pm 0,21$ & $7,24 \pm 0,19$ & $8,36 \pm 0,30$ & $6,02 \pm 0,16^{*},+$ \\
\hline Інсулін, Од/л & $8,54 \pm 0,76$ & $18,85 \pm 2,44$ & $14,17 \pm 2,26$ & $21,32 \pm 2,45$ & $11,33 \pm 0,84^{*}$ \\
\hline С-пептид, нг/мл & $4,07 \pm 0,28$ & $12,11 \pm 1,96$ & $8,23 \pm 0,87$ & $13,66 \pm 2,17$ & $6,14 \pm 0,50 *$ \\
\hline HOMA-IR & $1,63 \pm 0,37$ & $6,15 \pm 0,86$ & $5,11 \pm 0,85$ & $5,98 \pm 0,74^{*}$ & $4,08 \pm 0,26+$ \\
\hline
\end{tabular}

Примітка. Показник у хворих до та після лікування по групах достовірний: * - p<0,05; різниця між показником у хворих I та II груп після лікування достовірна: +- p $<0,05$.

Із наведених нижче результатів видно, що у всіх хворих до лікування були порушення ліпідного профілю.

Слід зазначити, що призначення лише БЛ хворим на ЦД 2-го типу та ХП не впливає на показники ліпідного обміну у даних пацієнтів, тоді як додаткове призначення L-Бетаргіну приводить до статистично достовірного зниження 3Х, ТГ, ЛПНЩ та лПДНЩ (р<0,05) (табл. 3).

У хворих на ЦД 2-го типу та ХП виявлено виражений дефіцит вітамінів групи В на фоні гіпергомоцистеїнемії у сироватці крові. Комплексна терапія із використанням амінокислотного комплексу приводить до нормалізації вітамінного забезпечення (ві- таміни групи В) на фоні зниження рівня гомоцистеїну в сироватці крові у даних пацієнтів (табл. 4).

Отже, встановлені зміни вказують на можливість ефективного використання L-Бетаргіну в складі комплексного лікування у хворих на ЦД 2-го типу та ХП для нормалізації клінічних проявів ЗСН ПЗ, а також показників вуглеводного, ліпідного обмінів. Слід зазначити, що даний амінокислотний комплекс має виражений позитивний вплив на показники вітамінів групи $\mathrm{B}$, що супроводжується зниженням рівня гомоцистеїну в сироватці крові, а це, в свою чергу, знижує ризик тромбоутворення та прогресування атерогенної дисліпідемії у даних пацієнтів.

Таблиця 3. Динаміка показників ліпідного обміну в обстежених хворих на ЦД 2-го типу та хронічний панкреатит на фоні проведеного лікування

\begin{tabular}{|c|c|c|c|c|c|}
\hline \multirow{3}{*}{ Показник, ммоль/л } & \multirow{3}{*}{$\begin{array}{c}\text { Контрольна } \\
\text { група } \\
(n=20)\end{array}$} & \multicolumn{4}{|c|}{ Обстежені хворі } \\
\hline & & \multicolumn{2}{|c|}{ І група $(n=40)$} & \multicolumn{2}{|c|}{ II група (n=36) } \\
\hline & & до лікування & після лікування & до лікування & до лікування \\
\hline $3 x$ & $4,26 \pm 0,15$ & $6,31 \pm 0,42$ & $6,18 \pm 0,48$ & $6,28 \pm 0,89$ & $5,41 \pm 0,27 *,+$ \\
\hline ТГ & $1,04 \pm 0,23$ & $3,02 \pm 0,26$ & $2,91 \pm 0,22$ & $3,12 \pm 0,31$ & $2,31 \pm 0,24^{*}$ \\
\hline лПнщ & $1,84 \pm 0,15$ & $2,51 \pm 0,15$ & $2,44 \pm 0,12$ & $2,48 \pm 0,18$ & $1,89 \pm 0,46 *,+$ \\
\hline лПДНЩ & $0,59 \pm 0,11$ & $1,35 \pm 0,23$ & $1,23 \pm 0,21$ & $1,28 \pm 0,15$ & $0,89 \pm 0,11^{*},+$ \\
\hline ЛПВЩ & $1,80 \pm 0,09$ & $1,03 \pm 0,05$ & $1,15 \pm 0,14$ & $1,04 \pm 0,09$ & $1,37 \pm 0,22$ \\
\hline
\end{tabular}

Примітка. Показник у хворих до та після лікування по групах достовірний: * - p<0,05; різниця між показником у хворих I та II груп після лікування достовірна: $+-p<0,05$. 
Огляди літератури, оригінальні дослідження, погляд на проблему, випадок з практики, короткі повідомлення Таблиця 4. Динаміка показників вітамінів та гомоцистеїну в обстежених хворих на ЦД 2-го типу та хронічний панкреатит на фоні проведеного лікування

\begin{tabular}{|c|c|c|c|c|c|}
\hline \multirow{3}{*}{ Показник } & \multirow{3}{*}{$\begin{array}{c}\text { Контрольна } \\
\text { група } \\
(n=20)\end{array}$} & \multicolumn{4}{|c|}{ Обстежені хворі } \\
\hline & & \multicolumn{2}{|c|}{ I група $(n=40)$} & \multicolumn{2}{|c|}{ II група (n=36) } \\
\hline & & до лікування & після лікування & до лікування & до лікування \\
\hline Вітамін B $_{1}$ мкг/л & $73,2 \pm 2,4$ & $33,11 \pm 1,23$ & $31,18 \pm 2,18$ & $31,37 \pm 3,25$ & $44,15 \pm 2,28 *,+$ \\
\hline Вітамін В, мкг/л & $18,5 \pm 1,7$ & $6,87 \pm 0,45$ & $6,92 \pm 0,89$ & $6,51 \pm 0,26$ & $8,23 \pm 0,44^{*}$ \\
\hline Вітамін В, нг/мл & $14,5 \pm 0,9$ & $3,25 \pm 0,33$ & $3,38 \pm 0,15$ & $3,72 \pm 0,52$ & $5,22 \pm 0,17 *,+$ \\
\hline Вітамін B $_{12}$, пг/мл & $524,1 \pm 9,5$ & $145,16 \pm 7,11$ & $154,14 \pm 6,13$ & $151,13 \pm 4,15$ & $195,14 \pm 5,26 *,+$ \\
\hline $\begin{array}{l}\text { Гомоцистеїн, } \\
\text { мкмоль/л }\end{array}$ & $9,7 \pm 0,6$ & $31,17 \pm 0,27$ & $30,18 \pm 0,87$ & $33,26 \pm 0,67$ & $18,98 \pm 0,45^{* *},+$ \\
\hline
\end{tabular}

Примітка. Показник у хворих до та після лікування по групах достовірний: * - p<0,05; ** - p<0,01; різниця між показником у хворих I та II груп після лікування достовірна: + - p<0,05.

Різноспрямована позитивна дія проявляється завдяки компонентам препарату, а саме - іони цитрату, що містяться в L-Бетаргіні, сприяють процесу травлення у разі підвищеної кислотності, зменшують вираження ацидозу та диспептичних проявів (нудота, відчуття тяжкості в шлунку, метеоризм). Бетаїн бере участь у біосинтезі фосфоліпідів, транспорті ТГ, окисненні та утилізації жирів, має антифібротичну, протизапальну дію, сприяє зниженню рівня гомоцистеїну, що знижує ризик тромбоутворення. L-карнітин - вітаміноподібна речовина, що покращує метаболічні процеси і $\epsilon$ головним кофактором обміну жирних кислот, а також сприяє зменшенню вираження дисфункції мітохондрій та підвищенню енергетичного обміну в міокарді. L-карнітин сприяє виведенню з клітин токсичних речовин та шкідливих метаболітів, також сприяє зниженню рівня 3Х. Аргінін - амінокислота, яка бере участь у біосинтезі білка, в метаболізмі сечовини, сприяє ви- діленню кінцевих продуктів розпаду білка, посилює детоксикаційну функцію печінки та організму у цілому.

Отже, призначення L-Бетаргіну сприяє не лише нормалізації функціонального стану гепатобіліарної та серцево-судинної систем, а й нормалізації обміну речовин при такому метаболічно обумовленому захворюванні, як ЦД 2-го типу, особливо при його поєднанні з ХП.

Висновки. Комплексна терапія із використанням препарату L-Бетаргін $є$ ефективним методом для корекції клінічних та лабораторних порушень (показників ліпідного, вуглеводного обмінів, вітамінного забезпечення та рівня гомоцистеїну в сироватці крові) у хворих на ЦД 2-го типу та ХП.

Перспективи подальших досліджень. Подальше дослідження ефективних засобів для корекції клінічних та лабораторних порушень у хворих на ЦД 2-го типу та ХП.

\section{ЛІТЕРАТУРА}

1. ДавыдчикЭ.В.Взаимосвязьгипергомоцистеинемии с ишемической болезнью сердца и сахарным диабетом / Э. В. Давыдчик, В. А. Снежицкий, Л. В. Никонова // Журнал Гродненского государственного медицинского университа. - 2015. - № 1 (49). - С. 9-13.

2. Фадєєнко Г. Д. Ураження гастродуоденальної ділянки у хворих на цукровий діабет: клініко-популяційні аспекти / Г. Д. Фадєєнко, В. А. Чернишов // Ліки України. - 2011. - № 7 (153). - С. 48-50.

3. Клінічна ефективність препарату Антраль® у хворих на хронічний панкреатит / О. С. Хухліна, І. В. Дудка, Т. В. Дудка, В. С. Смандич // Здоров' я України. - 2020. № 3. - С. 17.

4. Коцаба Ю. Я. Актуальні аспекти застосування пробіотиків при дисбіозі товстої кишки / Ю. Я. Коцаба, Л. С. Бабінець // Сімейна медицина. - 2018. - № 4 (78). - С. 85-87.
5. Ларин А. С. Патогенетическая роль кишечного дисбиоза в развитии ожирения, инсулинорезистентности и сахарного диабета 2 типа / А. С. Ларин, С. М. Ткач // Здоров'я України. - 2016. - № 2 (40). - С. 20-21.

6. Степанов Ю. М. Новейшие технологии в теоретической и практической гастроэнтерологии / Ю. М. Степанов // Здоров' я України. - 2016. - № 13-14 (386-387). С. 20-21.

7. Уніфікований клінічний протокол первинної та вторинної (спеціалізованої) медичної допомоги: цукровий діабет 2 типу : Наказ Міністерства охорони здоров'я України від 21.12.2012 р. № 1118. - 118 с.

8. Адаптована клінічна настанова, заснована на доказах: цукровий діабет 2 типу : Наказ Міністерства охорони здоров'я України від 21 грудня 2012 р. № 1118. 343 c. 
Огляди літератури, оригінальні дослідження, погляд на проблему, випадок з практики, короткі повідомлення REFERENCE

1. Davydchyk, E.V., Snezhitskiy, V.A., \& Nikonova, L.V. (2015). Vzaimosvyaz gipergomotsisteiniemii s ishemichieskoi boleznyu serdtsa i sakharnym diabietom [Relationship of hyperhomocysteinemia with coronary heart disease and diabetes mellitus]. Zhurnal Grodnenskogo gosudarstvennogo meditsinskogo universiteta - Journal of Grodno State Medical University, 1 (49), 9-15 [in Russian].

2. Fadieienko, H.D., \& Chernyshov, V.A. (2011). Urazhennia hastroduodenalnoi dilianky u khvorykh na tsukrovyi diabet: kliniko-populyatsiini aspekty [Defeat of the gastroduodenal region in patients with diabetes mellitus: clinical and population aspects]. Liky Ukrainy - Medicines of Ukraine, 7 (153), 48-50 [in Ukrainian].

3. Huhlina, O.S., Dudka, I.V., Dudka, T.V., \& Smandich, V.S. (2020). Klinichna efektyvnist preparatu Antral ${ }^{\circledR}$ u khvorykh na khronichnyi pankreatyt [Clinical efficacy of Antral ${ }^{\circledR}$ in patients with chronic pancreatitis]. Zdorovia Ukrayiny - Health of Ukraine, 3, 17 [in Ukrainian].

4. Kocaba, Yu.Ya., \& Babinec, L.S. (2018). Aktualni aspekty zastosuvannia probiotykiv pry dysbiozi tovstoi kyshky [Topical aspects of the use of probiotics in colonic dysbiosis]. Simeyna medytsyna - Family Medicine, 4 (78), 85-87 [in Ukrainian].

5. Larin, A.S., \& Tkach, S.M. (2016). Patogeneticheskaya rol kishechnogo disbioza v razvitii ozhireniya, insulino-

rezistentnosti i sakharnogo diabeta 2 tipa [Pathogenetic role of intestinal dysbiosis in the development of obesity, insulin resistance and type 2 diabetes mellitus]. Zdorovia Ukrainy - Health of Ukraine, 2 (40), 20-21 [in Russian].

6. Stepanov, Yu.M. (2016). Noveyshiye tekhnologii v teoreticheskoy i prakticheskoy gastroenterologii [The newest technologies in theoretical and practical gastroenterology]. Zdorovia Ukrainy - Health of Ukraine, 13-14 (386-387), 20-21 [in Russian].

7. (2012). Ministerstvo okhorony zdorovia Ukrainy. Unifikovanyi klinichnyi protokol pervynnoi ta vtorynnoi (spetsializovanoi) medychnoi dopomohy: tsukrovyi diabet 2 typu. Nakaz Ministerstva okhorony zdorovia Ukrainy [Ministry of Health of Ukraine. Unified clinical protocol for primary and secondary (specialized) care: type 2 diabetes mellitus. Order of the Ministry of Health of Ukraine], 1118, 118 [in Ukrainian].

8. (2012). Ministerstvo okhorony zdorovia Ukrainy. Adaptovana klinichna nastanova, zasnovana na dokazakh: tsukrovyi diabet 2 typu. Nakaz Ministerstva okhorony zdorovia Ukrainy [Ministry of Health of Ukraine. Type 2 diabetes mellitus. Adapted clinical guideline based on evidence. Order of the Ministry of Health of Ukraine]., 1118, 343 [in Ukrainian].

\title{
ЦЕЛЕСООБРАЗНОСТЬ ИСПОЛЬЗОВАНИЯ ПРЕПАРАТА L-БЕТАРГИН У БОЛЬНЫХ САХАРНЫМ ДИАБЕТОМ 2 ТИПА И ХРОНИЧЕСКИМ ПАНКРЕАТИТОМ
}

\author{
ОЕ. С. Сирчак, В. Е. Барани, С. С. Сирчак, А. Ю. Рего \\ ГВУз «Ужгородский национальный университет»
}

РЕЗЮМЕ. В настоящее время как сахарный диабет (СД), так и хронический панкреатит (ХП) представляют серезную медико-социальную проблему в связи с увеличением распространенности и прогрессирующей тенденцией к их росту.

Цель - изучить клинико-лабораторную эффективность использования аминокислотного комплекса L-Бетаргин у больных СД 2-го типа и ХП.

Материал и методы. Обследовано 76 больных СД 2-го типа и ХП. Больные были поделены на две группы в зависимости от назначенного лечения: I группа ( $n=40)$ обследованных больных получала только базисное лечение (БЛ); II группе (n=36) обследованных пациентов дополнительно к БЛ назначали аминокислотный комплекс L-Бетаргин по 10 мл 3 раза в сутки в течение 1 месяца. Всем обследованным пациентам проведены общеклинические исследования, а также определение витаминного обеспечения и уровня гомоцистеина.

Результаты. Проведенная терапия оказалась более эффективной по влиянию на динамику клинических проявлений у больных II группы, которые дополнительно получали аминокислотный комплекс L-Бетаргин. При этом диспепсические проявления уменьшились в 4,7 раза, тогда как у больных I группы только в 2,6 раза (р<0,01). Дополнительное назначение аминокислотного комплекса к БЛ у обследованных больных способствовало более выраженной положительной динамике показателей углеводного обмена. Установлено статистически достоверное снижение уровней HbA1c (до $(6,02 \pm 0,16) \%)$, инсулина (до $(11,33 \pm 0,84)$ Ед/л), С-пептида $(д о ~(6,14 \pm 0,50)$ нг/мл),

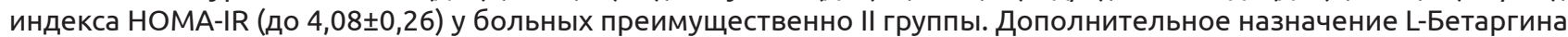
также приводит к статистически достоверному снижению уровней общего холестерина, триглицеридов, липопротеидов низкой плотности $(p<0,05)$ и повышению содержания витаминов группы $\mathrm{B}$, что сопровождается снижением показателя гомоцистеина у больных СД 2-го типа и ХП.

Выводы. Комплексная терапия с использованием препарата L-Бетаргин является эффективным методом для коррекции клинических и лабораторных нарушений (показателей липидного, углеводного обменов, витаминного обеспечения и уровня гомоцистеина в сыворотке крови) у больных СД 2-го типа и ХП.

КЛючЕВЫЕ СЛОВА: сахарный диабет 2-го типа; хронический панкреатит; лечение; L-Бетаргин. 
Огляди літератури, оригінальні дослідження, погляд на проблему, випадок з практики, короткі повідомлення EFFICACY OF L-BETARGIN APLICATION IN PATIENTS WITH TYPE 2 DIABETES AND CHRONIC PANCREATITIS

○Ye. S. Sirchak, V. Ye. Barani, S. S. Sirchak, A. Yu. Reho Uzhhorod National University

SUMMARY. Currently both diabetes mellitus (DM) and chronic pancreatitis (CP) pose a serious medical and social problem due to their increasing prevalence.

The aim - to research the clinical and laboratory efficacy of amino acid complex L-Betargin application in patients with type 2 diabetes and CP.

Material and Methods. 76 patients with type 2 diabetes and CP were examined and divided into two groups depending on the prescribed treatment. Group I $(n=40)$ of the examined patients received only basic treatment (BT); Group II $(n=36)$ of the examined patients was prescribed the amino acid complex L-Betargin $10 \mathrm{ml}$ three times a day for one month in addition to basic treatment. All examined patients underwent general clinical investigations and tested for vitamin supply and homocysteine levels.

Results. The therapy proved more efficient in terms of the dynamics of clinical manifestations in Group II patients, who additionally received the amino acid complex L-Betargin. Moreover, dyspepsia in Group II patients decreased 4.7 times as compared to 2.6 times $(p<0.01)$ decrease in Group I. The administration of the amino acid complex in addition to BT contributed to a more pronounced positive dynamics in carbohydrate metabolism in the examined patients. There was a statistically significant decrease in the level of HbA1c (up to $6.02 \pm 0.16 \%$ ), insulin (up to $11.33 \pm 0.84 \mathrm{U} / \mathrm{L}$ ), C-peptide (up to $6.14 \pm 0.50 \mathrm{ng} / \mathrm{mL}$ ), insulin resistance index (HOMA-IR) (up to $4.08 \pm 0.26$ ) mostly in Group II patients. The additional L-Betargin administration also leads to a statistically significant decrease in the levels of cholesterol, triglycerides, lowdensity lipoprotein cholesterol $(p<0.05)$ and an increase of $B$ vitamins, resulting in a homocysteine decrease in patients with type 2 diabetes and CP.

Conclusions. Complex therapy with L-Betargin is an efficient method for the correction of clinical and laboratory disorders (indicators of lipid and carbohydrate metabolism, vitamin supply and serum homocysteine levels) in patients with type 2 diabetes and CP.

KEY WORDS: diabetes mellitus type 2; chronic pancreatitis; treatment; L-Betargin. 